\title{
Association of the AGTR1 Gene A1166C (rs5186) Polymorphism with Essential Hypertension in the Indigenous Population of the Arctic
}

\author{
Sargylana I. Sofronova ${ }^{1 *}, \mathrm{PhD}$; Tatyana M. Klimova ${ }^{1,2}, \mathrm{PhD}$; \\ Marya P. Kirillina ${ }^{1}$, PhD; Vyacheslav M. Nikolaev ${ }^{1}, \mathrm{PhD}$; Irina V. Kononova ${ }^{1}$, PhD; \\ Ariana A. Kuzmina ${ }^{2}$, PhD; Anna N. Romanova ${ }^{1}$, MD \\ ${ }^{1}$ Yakut Science Centre of Complex Medical Problems \\ ${ }^{2}$ Institute of Medicine at M.K. Ammosov North-Eastern Federal University \\ Yakutsk, the Republic of Sakha (Yakutia), Russia
}

\begin{abstract}
The research objective was to study the association of the AGTR1 rs5186 SNP (the A1166C variant) with essential hypertension among indigenous people of the Arctic territory of Yakutia.

Methods and Results: A total of 351 participants (224 women and 127 men) were examined, including 56 Yakuts, 34 Chukchi, 77 Yukaghirs, and 184 Evens. The Case $(n=168)$ and Control $(n=183)$ groups were formed. Allelic variants of the AGTR1 rs5186 SNP were tested by real-time PCR. We did not find statistically significant differences in the frequency distribution of the alleles and genotypes of the AGTR1 rs5186 SNP between the Case group and the Control group.

Conclusion: The obtained data show no association of the AGTR1 A1166C polymorphism with EHT in the representatives of indigenous people of the Arctic territory of Yakutia.(International Journal of Biomedicine. 2021;11(3):361-366.)
\end{abstract}

Key Words: essential hypertension $\bullet$ genotype $\bullet A G T R 1$ gene $\bullet$ A1166C $\bullet$ rs5186 $\bullet$ Yakutia

For citation: Sofronova SI, Klimova TM, Kirillina MP, Nikolaev VM, Kononova IV, Kuzmina AA, Romanova AN. Association of the AGTR1 Gene A1166C (rs5186) Polymorphism with Essential Hypertension in the Indigenous Population of the Arctic. International Journal of Biomedicine. 2021;11(3):361-366. doi:10.21103/Article11(3)_OA14

\section{Abbreviations}

AGTR1, angiotensin II type I receptor; AO, abdominal obesity; AH, arterial hypertension; BP, blood pressure; DBP, diastolic BP; EHT, essential hypertension; FPG, fasting plasma glucose; GWAS, genome-wide association studies; HDL-C, highdensity lipoprotein cholesterol; HWE, Hardy-Weinberg equilibrium; LDL-C, low-density lipoprotein cholesterol; RAAS, reninangiotensin-aldosterone system; SBP, systolic BP; TC, total cholesterol; TG, triglycerides; WC, waist circumference.

\section{Introduction}

Arterial hypertension (AH) is still one of the most common problems in cardiology and is responsible for high cardiovascular morbidity and mortality. Essential hypertension (EHT) is a multifactorial disease with a complex genetic

*Corresponding author: Sargylana I. Sofronova, PhD. Yakut Science Center of Complex Medical Problems. Yakutsk, the Republic of Sakha (Yakutia),Russia.E-mail:sara2208@mail.ru basis. Large-scale GWAS have successfully established $\sim 800$ genetic loci for SBP, DBP, and hypertension in multiple ethnic groups. ${ }^{(1)}$ Several reviews and meta-analyses summarize the vast number of studies of the RAAS genes in cardiovascular physiology, disease, and treatment. ${ }^{(2-4)}$ The RAAS plays a fundamental role in blood pressure maintenance and is implicated in the pathogenesis of hypertension. However, the results of the gene studies of individual RAAS candidates vary depending on population or ethnicity. Among the great number of gene candidates encoding the RAAS components, the ATIR gene is of great interest. Polymorphisms within this gene have 
been extensively studied in association with hypertension; however, findings are conflicting. ${ }^{(5)}$

The most well-studied of the AGTR1 SNP is rs5186 (also termed the A1166C variant) located in the 3' UTR. Frequencies of this variant range from $0.19-0.31$ in populations of European descent, ${ }^{(6-9)} 0.03-0.11$ in populations of Asian descent, ${ }^{(10-13)}$ and $0.05-0.08$ in studies of populations of African descent. Numerous studies have been published associating polymorphisms of the AGTRl gene with $\mathrm{AH}$; however, results have been inconsistent. ${ }^{(5,17,18)}$

It has been hypothesized that the AGTR1 rs5186 SNP, an AC nucleotide substitution at position 1166 in the $3^{\prime}$ untranslated region of chromosome 3 , may affect mRNA155 stability and transcription. In some populations, a link between being a carrier of the C allele rs5186 and an increased risk of developing essential hypertension has been demonstrated. ${ }^{(17,18)}$

The Republic of Sakha (Yakutia) $(\mathrm{RS}(\mathrm{Y}))$ is a region where extreme climatic factors have a depleting effect on the functional reserves of the human body. The tension of the adaptive mechanisms often manifests itself in the form of an increase in BP. Changes in diet and physical activity have led to widespread overweight and obesity among indigenous populations of the North, which also contributes to an increase in BP. ${ }^{(19)}$ Under these conditions, the search for genetic markers of predisposition to the development of hypertension is of both scientific and practical interest

Our research objective was to study the association of the AGTR1 rs5186 SNP (the A1166C variant) with EHT among indigenous people of the Arctic territory of Yakutia.

\section{Materials and Methods}

A one-stage epidemiological study was carried out in the Arctic territory of the RS(Y). The Case (EHT+) and Control (EHT-) groups were formed. A total of 351 participants (224 women and 127 men) were examined, including 56 Yakuts, 34 Chukchi, 77 Yukaghirs, and 184 Evens. The average age was $45.9 \pm 12.5$ years. Nationality was determined through participants' self-identification.

The study was approved by the Ethics Committee of the Yakut Science Center of Complex Medical Problems. Written informed consent was obtained from each patient.

Inclusion criteria for the Case group $(n=168)$ were representatives with EHA of indigenous peoples of Yakutia (the Yakuts, the Evens, the Chukchi, the Yukaghir), and being 18 years and older. Inclusion criteria for the Control group $(n=183)$ were representatives without EHT of indigenous peoples of Yakutia (the Yakuts, the Evens, the Chukchi, the Yukaghir), and being 18 years and older. Exclusion criteria were representatives of non-indigenous nationality and those with secondary hypertension.

The research program included the following sections: a questionnaire for objective assessment of state; informed consent of the respondent to conduct research and donate blood; anthropometric examination; and blood sampling from the cubital vein in the morning on an empty stomach, with 12hour abstinence from food.
Abdominal obesity (AO) was confirmed at $\mathrm{WC} \geq 94 \mathrm{~cm}$ in males and $\geq 80 \mathrm{~cm}$ in females (VNOK, 2009).

Blood pressure (BP) was measured twice with an OMRON M2 Basic automatic tonometer, with subjects in a sitting position. Average BP was calculated with a margin of permissible measurement error of $\pm 3 \mathrm{mmHg}$, according to the instructions for the correct measurement of BP outlined in the European clinical guidelines for the diagnosis and treatment of hypertension. The diagnosis of AH was based on 2017 ACC/ AHA Guideline for or the Prevention, Detection, Evaluation, and Management of High Blood Pressure in Adults. ${ }^{(20)}$

Laboratory methods of the research included the assessment of FPG and blood levels of TG, HDL-C, and LDL-C. Lipid metabolism disorders were diagnosed according to the Russian national recommendations of the VII revision(the Russian Society of Cardiologists [RSC, 2020]), considering the European recommendations (2019): TC >5,0 mmol/1; TG>1.7 $\mathrm{mmol} / \mathrm{l}$; HDL-C $<1.0 \mathrm{mmol} / 1$ in males and $<1.2 \mathrm{mmol} / 1$ in females; LDL-C $>3.0 \mathrm{mmol} / \mathrm{l}$. The atherogenic index (IA) was determined by the formula: IA=(TC-HDL-C)/HDL-C (Klimov AN, Nikulcheva NG, 1999). Impaired fasting glucose was defined as FPG level $>5.6 \mathrm{mmol} / \mathrm{l}$. Respondents with these disorders also included participants receiving specific medication for these conditions.

\section{Genotyping of the AGTR1 rs5186 SNP (the A1166C variant)}

Genomic DNA was isolated from the peripheral blood leukocytes using a standard phenol-chloroform extraction technique. Allelic variants of the AGTR1 rs5186 SNP_were tested by real-time PCR on the «Real-time CFX96» amplifier (BioRad, USA) using Lytech kits (Lytech R\&D LLC, Moscow) in accordance with the manufacturer's instructions. For quality control, 10\% of samples were randomly repeated, with complete congruence.

Statistical analysis was performed using IBM SPSS Statistics for Windows, Version 22.0 (Armonk, NY: IBM Corp.). Baseline characteristics were summarized as frequencies and percentages for categorical variables and as median (interquartile range (IQR; 25th to 75th percentiles) for continuous variables. Mann-Whitney U test and Kruskal-Wallis test were used, respectively, to compare differences between 2 and 3 or more independent groups. Odds ratios (ORs) and 95\% confidence intervals (CIs) were calculated. Deviation from Hardy-Weinberg equilibrium and differences in allele distributions between the two groups were assessed by $\chi^{2}$ - test with 1 degree of freedom (df). A probability value of $P<0.05$ was considered statistically significant.

\section{Results and Discussion}

The frequencies of the AA, AC and $\mathrm{CC}$ genotypes of the AGTR1 rs5186 SNP (the A1166C variant) in the groups of Yakuts, Evens, and Yukaghirs corresponded to the HWE. In the Chukchi group, which was represented by 34 participants, the distribution of the genotype frequency was not in the HWE (Table 1).

The frequency of the $\mathrm{C}$ allele varied from 0.13 in the Evens to 0.35 in the Chukchi. According to the ALFA (Allele 
Frequency Aggregator) project, the frequency of the $\mathrm{C}$ allele carriage averages $0.28(\mathrm{n}=238604)$, varying, depending on population, from 0.009 among Africans $(\mathrm{n}=354)$ to 0.30 among Hispanics $(\mathrm{n}=6874)$. Among the populations of Southeast Asia, the prevalence of the C allele is $0.08-0.09$. ${ }^{(21)}$ Thus, according to the presented study, the frequency of the $\mathrm{C}$ allele in the indigenous ethnic groups of Yakutia is, on average, higher than in the populations of Southeast Asia and Africa.
We did not find statistically significant differences in the frequency distribution of the alleles and genotypes of the AGTR1 rs5186 SNP between the Case group and the Control group (Table 2).

In research literature, the data on the link between the AGTR1 rs5186 SNP and essential hypertension is contradictory. ${ }^{(17,18,22-25)}$ Regarding China, a comparison of three genetically different populations with significant differences in the prevalence of EHT suggested that the A allele may

Table 1.

The frequency distribution of the alleles and genotypes of the AGTR1 rs5186 SNP (the A1166C variant) in the groups of Yakuts. Evens. and Yukaghirs

\begin{tabular}{|c|c|c|c|c|c|c|}
\hline $\begin{array}{c}\text { Allele } \\
\text { /Genotype }\end{array}$ & Indicator & $\begin{array}{l}\text { Yakuts } \\
(\mathrm{n}=56)\end{array}$ & $\begin{array}{c}\text { Evens } \\
(\mathrm{n}=184)\end{array}$ & $\begin{array}{c}\text { Chukchi } \\
(\mathrm{n}=34)\end{array}$ & $\begin{array}{c}\text { Yukaghirs } \\
(\mathrm{n}=77)\end{array}$ & $\begin{array}{c}\text { Total } \\
(\mathrm{n}=351)\end{array}$ \\
\hline \multirow[b]{2}{*}{ A } & Total & 90 & 321 & 44 & 116 & 571 \\
\hline & $\begin{array}{l}\text { Frequency } \\
(95 \% \text { CI })\end{array}$ & $80.4(71.5-87.2)$ & $87.2(83.3-90.4)$ & $64.7(51.9-75.9)$ & $80.6(72.9-86.6)$ & $81.3(78.3-84.1)$ \\
\hline \multirow[b]{2}{*}{$\mathrm{C}$} & Total & 22 & 47 & 24 & 38 & 131 \\
\hline & $\begin{array}{l}\text { Frequency } \\
(95 \% \text { CI })\end{array}$ & $19.6(12.8-28.5)$ & $12.8(9.6-16.7)$ & $35.3(24.1-48.1)$ & $26.4(19.5-34.5)$ & $18.7(15.9-21.7)$ \\
\hline \multirow[b]{2}{*}{ AA } & Total & 36 & 140 & 10 & 43 & 229 \\
\hline & $\begin{array}{l}\text { Frequency } \\
(95 \% \text { CI })\end{array}$ & $64.3(50.0-76.7)$ & $76.1(69.2-81.9)$ & $29.4(14.5-48.5)$ & $55.8(44.0-67.1)$ & $65.2(60.0-70.1)$ \\
\hline \multirow[b]{2}{*}{$\mathrm{AC}$} & Total & 18 & 41 & 24 & 30 & 113 \\
\hline & $\begin{array}{l}\text { Frequency } \\
(95 \% \text { CI })\end{array}$ & $32.1(20.2-46.4)$ & $22.3(16.6-29.1)$ & $70.6(51.5-85.5)$ & $38.9(28.1-50.9)$ & $32.2(27.4-37.3)$ \\
\hline \multirow[b]{2}{*}{$\mathrm{CC}$} & Total & 2 & 3 & 0 & 4 & 9 \\
\hline & $\begin{array}{l}\text { Frequency } \\
(95 \% \text { CI })\end{array}$ & $3.6(0-14.3)$ & $1.6(0-5.3)$ & 0 & $5.2(0.7-14.0)$ & $2.6(1.1-5.0)$ \\
\hline \multicolumn{2}{|c|}{$\chi^{2}(\mathrm{HWE})$} & 0.019 & 8.08 & 10.1 & 0.179 & 1.284 \\
\hline \multicolumn{2}{|l|}{$P$-value } & 0.892 & 0.99 & 0.001 & 0.673 & 0.257 \\
\hline
\end{tabular}

Table 2.

The frequency distribution of the alleles and genotypes of the AGTR1 rs5186 SNP (the A1166C variant) between the Case group and the Control group

\begin{tabular}{|c|c|c|c|c|c|}
\hline \multirow{2}{*}{ Ethnos } & \multirow{2}{*}{ Group } & \multicolumn{3}{|c|}{ Allele/Genotype, n (\%) } & \multirow{2}{*}{ OR $(95 \% \mathrm{CI}) ; P$-value } \\
\hline & & A & & & \\
\hline \multirow{2}{*}{ Yakuts } & EHT- & $31(77.5)$ & \multicolumn{2}{|c|}{$9(22.5)$} & \multirow{2}{*}{$0.76(0.29-1.97) ; P=0.750$} \\
\hline & EHT+ & $59(81.9)$ & \multicolumn{2}{|c|}{$13(18.1)$} & \\
\hline \multirow{2}{*}{ Evens } & EHT- & $176(87.1)$ & \multicolumn{2}{|c|}{$26(12.9)$} & \multirow{2}{*}{$0.98(0.53-1.8) ; P=1.0$} \\
\hline & EHT+ & $145(87.3)$ & \multicolumn{2}{|c|}{$21(12.7)$} & \\
\hline \multirow{2}{*}{ Chukchi } & EHT- & $29(65.9)$ & \multicolumn{2}{|c|}{$15(34.1)$} & \multirow{2}{*}{$1.16(0.41-3.27) ; P=0.988$} \\
\hline & EHT+ & $15(62.5)$ & \multicolumn{2}{|c|}{$9(37.5)$} & \\
\hline \multirow{2}{*}{ Yukaghirs } & EHT- & $59(73.8)$ & \multicolumn{2}{|c|}{$21(2.2)$} & \multirow{2}{*}{$0.84(0.40-1.75) ; P=0.776$} \\
\hline & EHT+ & $57(77.0)$ & \multicolumn{2}{|c|}{$17(23.0)$} & \\
\hline \multirow{2}{*}{ All groups } & EHT - & $295(80.6)$ & \multicolumn{2}{|c|}{$71(19.4)$} & \multirow{3}{*}{$0.90(0.62-1.32) ; P=0.600$} \\
\hline & EHT+ & $276(82.1)$ & \multicolumn{2}{|c|}{$60(17.9)$} & \\
\hline & & AA & $\mathrm{AC}$ & $\mathrm{CC}$ & \\
\hline \multirow{2}{*}{ Yakuts } & EHT- & $12(60)$ & $7(35.0)$ & $1(5.0)$ & \multirow{2}{*}{$\begin{array}{l}\text { AA and AC: } 0.79(0.24-2.54) ; P=0.920 \\
\text { AA and CC: } 0.50(0.03-8.71) ; P=1.0 \\
\text { AA and AC+CC: } 0.75(0.24-2.33) ; P=0.835\end{array}$} \\
\hline & EHT+ & $24(66.7)$ & $11(30.6)$ & $1(2.8)$ & \\
\hline \multirow[b]{2}{*}{ Evens } & EHT- & $77(76.2)$ & $22(21.8)$ & $2(2.0)$ & \multirow{2}{*}{$\begin{array}{l}\text { AA and AC: } 1.06(0.53-2.12) ; P=1.0 \\
\text { AA and CC: } 0.61(0.05-6.89) ; P=1.0 \\
\text { AA and AC+CC: } 1.02(0.52-2.0) ; P=1.0\end{array}$} \\
\hline & EHT+ & $63(75.9)$ & $19(22.9)$ & $1(1.2)$ & \\
\hline \multirow{2}{*}{ Chukchi } & EHT- & $7(31.8)$ & $15(68.2)$ & & \multirow{2}{*}{ AA and AC: $1.40(0.29-6.83) ; P=0.982$} \\
\hline & EHT+ & $3(25.0)$ & $9(72.0)$ & & \\
\hline \multirow{2}{*}{ Yukaghirs } & EHT- & $22(55.0)$ & $15(37.5)$ & $3(7.5)$ & \multirow{2}{*}{$\begin{array}{l}\text { AA and AC: } 1.05(0.41-2.66) ; P=0.922 \\
\text { AA and CC: } 0.35(0.03-3.63) ; P=0.696 \\
\text { AA and AC+CC: } 0.93(0.38-2.29) ; P=1.0\end{array}$} \\
\hline & EHT + & $21(56.8)$ & $15(40.5)$ & $1(2.7)$ & \\
\hline \multirow[b]{2}{*}{ Total } & EHT- & $118(64.5)$ & $59(32.2)$ & $6(3.3)$ & \multirow{2}{*}{$\begin{array}{l}\text { AA and AC: } 0.97(0.62-1.55) ; P=0.997 \\
\text { AA and CC: } 0.53(0.13-2.18) ; P=0.581 \\
\text { AA and AC+CC: } 0.93(0.60-1.45) ; P=0.841\end{array}$} \\
\hline & EHT+ & $111(66.1)$ & $54(32.1)$ & $3(1.8)$ & \\
\hline
\end{tabular}


be a predisposing factor for EHT in Tibetan men, while no association was found in the other two populations. ${ }^{(22)}$ In a casecontrol study conducted in Poland (250 patients with stable EHT and 150 individuals with normal BP), the $\mathrm{C}$ allele and $\mathrm{CC}$ genotype were statistically significantly more frequent in patients with hypertension. ${ }^{(25)}$ In a similar study conducted in India, individuals with the $\mathrm{CC}$ genotype were 2.4 times more likely to develop $\operatorname{EHT}(P=0.0001)$ than individuals with the AC and AA genotypes. ${ }^{(23)}$ At the same time, in the study by Suita, conducted in Japan, involving 1492 hypertensive subjects and 2426 normotensive subjects, no association was found between the A1166C variants of the AGTR1 gene and hypertension. ${ }^{(24)}$ Similar results were obtained by researchers in Tunisia. ${ }^{(26)}$
The AGTR1 A1166C polymorphism was found to be linked to the presence and severity of nonalcoholic fatty liver disease, nonalcoholic steatohepatitis, liver fibrosis, dyslipidemia, insulin resistance, and metabolic syndrome. ${ }^{(27-}$ ${ }^{30)}$ Considering the above data, in our analysis, the carriers of the $\mathrm{A}$ allele and $\mathrm{C}$ allele were compared in terms of the level of metabolic parameters (Table 3 ). The carriers of different alleles and genotypes were comparable in age and gender structure. We did not find any differences in BP levels between carriers of different genotypes. It should be noted that the levels of SBP and DBP were compared for all study participants, including those taking antihypertensive drugs, which could change the results obtained.

Table 3.

Comparison of age and metabolic parameters in carriers of different alleles and genotypes of the A1166C polymorphism of the AT1R gene

\begin{tabular}{|c|c|c|c|c|}
\hline Indicator & \multicolumn{3}{|c|}{$\operatorname{Me}\left(Q_{1}-Q_{3}\right)$} & $P$-value \\
\hline & \multicolumn{3}{|c|}{ Allele } & \\
\hline & \multicolumn{2}{|c|}{$\mathrm{A}$} & $\mathrm{C}$ & \\
\hline Age, years & \multicolumn{2}{|c|}{$48.0(36.0-55.0)$} & $47.0(35.0-55.0)$ & 0.987 \\
\hline $\mathrm{WC}, \mathrm{cm}$ & \multicolumn{2}{|c|}{$88.0(78.0-98.0)$} & $83.0(35.0-98.0)$ & 0.044 \\
\hline $\mathrm{SBP}, \mathrm{mmHg}$ & \multicolumn{2}{|c|}{$130.0(120.0-150.0)$} & $130.0(35.0-150.0)$ & 0.337 \\
\hline $\mathrm{DBP}, \mathrm{mmHg}$ & \multicolumn{2}{|c|}{$80.0(80.0-90.0)$} & $80.0(35.0-90.0)$ & 0.347 \\
\hline FPG, $\mathrm{mmol} /$ & \multicolumn{2}{|c|}{$4.4(3.9-5.0)$} & $4.2(35.9-5.0)$ & 0.099 \\
\hline $\mathrm{TG}, \mathrm{mmol} / \mathrm{l}$ & \multicolumn{2}{|c|}{$1.0(0.7-1.4)$} & $0.9(35.7-1.4)$ & 0.129 \\
\hline $\mathrm{TC}, \mathrm{mmol} / \mathrm{l}$ & \multicolumn{2}{|c|}{$4.9(4.4-5.5)$} & $4.9(35.4-5.5)$ & 0.385 \\
\hline HDL-C, mmol/1 & \multicolumn{2}{|c|}{$1.2(1.0-1.5)$} & $1.4(35.0-1.5)$ & 0.011 \\
\hline LDL-C, $\mathrm{mmol} / \mathrm{l}$ & \multicolumn{2}{|c|}{$3.2(2.7-3.7)$} & $3.0(35.7-3.7)$ & 0.122 \\
\hline VHDL-C, mmol/1 & \multicolumn{2}{|c|}{$0.4(0.3-0.6)$} & $0.4(35.3-0.6)$ & 0.069 \\
\hline IA & \multicolumn{2}{|c|}{$2.9(2.2-3.8)$} & $2.7(35.2-3.8)$ & 0.014 \\
\hline \multicolumn{5}{|c|}{ Genotype } \\
\hline & AA & $\mathrm{AC}$ & $\mathrm{CC}$ & \\
\hline Age, years & $47.0(35.0-55.0)$ & $48.0(37.8-55.0)$ & $33.0(29.5-58.5)$ & 0.576 \\
\hline $\mathrm{WC}, \mathrm{cm}$ & $88.5(78.3-98.0)$ & $86.0(37.0-98.0)$ & $81.0(75.3-82.0)$ & 0.032 \\
\hline $\mathrm{SBP}, \mathrm{mmHg}$ & $130.0(120.0-150.0)$ & $130.0(37.0-150.0)$ & $120.0(117.5-145.0)$ & 0.565 \\
\hline $\mathrm{DBP}, \mathrm{mmHg}$ & $80.0(80.0-90.0)$ & $80.0(37.0-90.0)$ & $80.0(77.5-90.0)$ & 0.569 \\
\hline FPG, mmol/1 & $4.5(4.0-5.0)$ & $4.3(37.8-5.0)$ & $3.8(3.3-4.4)$ & 0.121 \\
\hline $\mathrm{TG}, \mathrm{mmol} / \mathrm{l}$ & $1.0(0.7-1.4)$ & $0.9(37.7-1.4)$ & $0.9(0.7-1.1)$ & 0.295 \\
\hline $\mathrm{TC}, \mathrm{mmol} / \mathrm{l}$ & $4.9(4.4-5.5)$ & $4.9(37.3-5.5)$ & $4.9(4.1-5.5)$ & 0.669 \\
\hline HDL-C, mmol/1 & $1.2(1.0-1.5)$ & $1.3(37.1-1.5)$ & $1.4(1.2-1.6)$ & 0.027 \\
\hline LDL-C, $\mathrm{mmol} / \mathrm{l}$ & $3.2(2.7-3.7)$ & $3.0(37.6-3.7)$ & $3.1(2.6-3.6)$ & 0.261 \\
\hline VHDL-C, mmol/1 & $0.4(0.3-0.7)$ & $0.4(37.3-0.7)$ & $0.4(0.3-0.5)$ & 0.170 \\
\hline \multirow[t]{2}{*}{ IA } & $3.0(2.2-4.0)$ & $2.7(37.0-4.0)$ & $2.6(2.0-3.5)$ & 0.034 \\
\hline & \multicolumn{2}{|c|}{$\mathrm{AA}$} & $\mathrm{AC}+\mathrm{CC}$ & \\
\hline Age, years & \multicolumn{2}{|c|}{$47.0(35.0-55.0)$} & $47.5(36.8-55.0)$ & 0.750 \\
\hline $\mathrm{WC}, \mathrm{cm}$ & \multicolumn{2}{|c|}{88.5 (78.3-98.0) } & $84.5(77.0-98.0)$ & 0.127 \\
\hline SBP, $\mathrm{mmHg}$ & \multicolumn{2}{|c|}{$130.0(120.0-150.0)$} & $130.0(120.0-150.0)$ & 0.405 \\
\hline DBP, $\mathrm{mmHg}$ & \multicolumn{2}{|c|}{$80.0(80.0-90.0)$} & $80.0(80.0-90.0)$ & 0.292 \\
\hline FPG, mmol/1 & \multicolumn{2}{|c|}{$4.5(4.0-5.0)$} & $4.2(3.8-5.0)$ & 0.194 \\
\hline $\mathrm{TG}, \mathrm{mmol} / \mathrm{l}$ & \multicolumn{2}{|c|}{$1.0(0.7-1.4)$} & $0.9(0.7-1.4)$ & 0.134 \\
\hline $\mathrm{TC}, \mathrm{mmol} / \mathrm{l}$ & \multicolumn{2}{|c|}{$4.9(4.4-5.5)$} & $4.9(4.2-5.5)$ & 0.394 \\
\hline HDL-C, mmol/1 & \multicolumn{2}{|c|}{$1.2(1.0-1.5)$} & $1.3(1.1-1.5)$ & 0.007 \\
\hline LDL-C, $\mathrm{mmol} / \mathrm{l}$ & \multicolumn{2}{|c|}{$3.2(2.7-3.7)$} & $3.0(2.6-3.7)$ & 0.102 \\
\hline VHDL-C, mmol/1 & \multicolumn{2}{|c|}{$0.4(0.3-0.7)$} & $0.4(0.3-0.7)$ & 0.065 \\
\hline IA & $3.0(2$. & $-4.0)$ & $2.7(2.0-4.0)$ & 0.010 \\
\hline
\end{tabular}


Carriers of the A allele and AA genotype were characterized by a statistically significantly larger WC, lower HDL-C level, and high values of the atherogenic index (Table 3 ). In carriers of the $\mathrm{AC}+\mathrm{CC}$ genotypes, the identified features persisted.

We found a significantly higher incidence of decreased HDL-C level in carriers of the A allele than in carriers of the $\mathrm{C}$ allele (38.1\% vs. $27.7 \%, P=0.026)$, and a higher incidence in AA carriers than in carriers of the $\mathrm{AC}$ and $\mathrm{CC}$ genotypes (40.5\%, 28.6\%, 22.2\%, respectively; $P=0.005)$.

The HDL-C level did not correlate with the age of the subjects $(\mathrm{r}=-0.07, P=0.076)$. No correlation was found between the HDL-C level and SBP $(\mathrm{r}=-0.06, P=0.113)$, DBP $(\mathrm{r}=-0.09$, $P=0.013)$, FPG $(\mathrm{r}=-0.07, P=0.069)$, LDL-C $(\mathrm{r}=-0.03, P=0.412)$. Negative correlations were found between the HDL-C level and $\mathrm{WC}(\mathrm{r}=-0.26, P<0.001)$ and TG levels $(\mathrm{r}=-0.58, P<0.001)$. The revealed differences in the HDL-C levels in carriers of different genotypes and alleles of the AGTR1 A1166C polymorphism were associated with differences in WC.

\section{Conclusion}

The obtained data show no association of the AGTR1 A1166C polymorphism with EHT in the representatives of indigenous people of the Arctic territory of Yakutia. The limitations of the study were: the small number of groups and the inability to conduct a full, comprehensive examination of the participants to exclude the secondary nature of hypertension. A positive aspect of the research was the usage of controls from the same population, in the same time period. In further studies, an additional verification of the studied link would be possible by using the hospital population as "cases," excluding the secondary nature of hypertension

\section{Competing Interests}

The authors declare that they have no competing interests.

\section{References}

1. Evangelou E, Warren HR, Mosen-Ansorena D, Mifsud B, Pazoki R, Gao H, et al.; Million Veteran Program. Genetic analysis of over 1 million people identifies 535 new loci associated with blood pressure traits. Nat Genet. 2018 Oct;50(10):1412-1425. doi: 10.1038/s41588-018-0205-x.

2. Jeunemaitre $X$. Genetics of the human renin angiotensin system. J Mol Med (Berl). 2008 Jun;86(6):637-41. doi: 10.1007/s00109-008-0344-0.

3. Konoshita T; Genomic Disease Outcome Consortium (G-DOC) Study Investigators. Do genetic variants of the Renin-Angiotensin system predict blood pressure response to Renin-Angiotensin system-blocking drugs?: a systematic review of pharmacogenomics in the Renin-Angiotensin system. Curr Hypertens Rep. 2011 Oct;13(5):356-61. doi: 10.1007/s11906-011-0212-0.

4. Braliou GG, Grigoriadou AM, Kontou PI, Bagos PG. The role of genetic polymorphisms of the Renin-Angiotensin System in renal diseases: A meta-analysis. Comput Struct
Biotechnol J. 2014 Jun 11;10(16):1-7. doi: 10.1016/j. csbj.2014.05.006.

5. Mottl AK, Shoham DA, North KE. Angiotensin II type 1 receptor polymorphisms and susceptibility to hypertension: a HuGE review. Genet Med. 2008 Aug;10(8):560-74. doi: 10.1097/gim.0b013e3181809613

6. Zhang X, Erdmann J, Regitz-Zagrosek V, Kürzinger S, Hense HW, Schunkert H. Evaluation of three polymorphisms in the promoter region of the angiotensin II type I receptor gene. J Hypertens. 2000 Mar;18(3):267-72. doi: 10.1097/00004872200018030-00005.

7. Kee F, Morrison C, Poirier O, McCrum E, Mallet C, Nicaud V, McMaster D, Dallongeville J, Fruchart JC, Evans AE. Angiotensin II type-I receptor and ACE polymorphisms and risk of myocardial infarction in men and women. Eur $\mathrm{J}$ Clin Invest. 2000 Dec;30(12):1076-82. doi: 10.1046/j.13652362.2000.00741.x.

8. Hindorff LA, Heckbert SR, Tracy R, Tang Z, Psaty BM, Edwards KL, Siscovick DS, Kronmal RA, NazarStewart V. Angiotensin II type 1 receptor polymorphisms in the cardiovascular health study: relation to blood pressure, ethnicity, and cardiovascular events. Am J Hypertens. 2002 Dec;15(12):1050-6. doi: 10.1016/s0895-7061(02)03063-7.

9. Ermis C, Tsai MY, Hanson NQ, Akar N, Aras O. Angiotensin I converting enzyme, angiotensin II type 1 receptor and angiotensinogen polymorphisms and early myocardial infarction in Turkish population. Thromb Haemost. 2002 Oct;88(4):693-4.

10. Kato N, Sugiyama T, Morita H, Kurihara H, Furukawa T, Isshiki T, Sato T, Yamori Y, Yazaki Y. Comprehensive analysis of the renin-angiotensin gene polymorphisms with relation to hypertension in the Japanese. J Hypertens. 2000 Aug;18(8):1025-32. doi: 10.1097/00004872-20001808000006.

11. Tabara Y, Kohara K, Miki T. Polymorphisms of genes encoding components of the sympathetic nervous system but not the renin-angiotensin system as risk factors for orthostatic hypotension. J Hypertens. 2002 Apr;20(4):651-6. doi: 10.1097/00004872-200204000-00022.

12. Ono K, Mannami T, Baba S, Yasui N, Ogihara T, Iwai N. Lack of association between angiotensin II type 1 receptor gene polymorphism and hypertension in Japanese. Hypertens Res. 2003 Feb;26(2):131-4. doi: 10.1291/hypres.26.131.

13. Sugimoto K, Katsuya T, Ohkubo T, Hozawa A, Yamamoto K, Matsuo A, Rakugi H, Tsuji I, Imai Y, Ogihara T. Association between angiotensin II type 1 receptor gene polymorphism and essential hypertension: the Ohasama Study. Hypertens Res. 2004 Aug;27(8):551-6. doi: 10.1291/hypres.27.551.

14. Hsu CC, Bray MS, Kao WH, Pankow JS, Boerwinkle E, Coresh J. Genetic variation of the renin-angiotensin system and chronic kidney disease progression in black individuals in the atherosclerosis risk in communities study. J Am Soc Nephrol. 2006 Feb;17(2):504-12. doi: 10.1681/ASN.2005050468.

15. Hooper WC, Dowling NF, Wenger NK, Dilley A, Ellingsen D, Evatt BL. Relationship of venous thromboembolism and myocardial infarction with the renin-angiotensin system in African-Americans. Am J Hematol. 2002 May;70(1):1-8. doi: 10.1002/ajh.10078.

16. Ranjith N, Pegoraro RJ, Rom L, Lanning PA, Naidoo DP. Renin-angiotensin system and associated gene polymorphisms in myocardial infarction in young South African Indians. Cardiovasc J S Afr. 2004 Jan-Feb;15(1):22-6.

17. Jiang Z, Zhao W, Yu F, Xu G. Association of angiotensin 
II type 1 receptor gene polymorphism with essential hypertension. Chin Med J (Engl). 2001 Dec;114(12):1249-51. 18. Wang WY, Zee RY, Morris BJ. Association of angiotensin II type 1 receptor gene polymorphism with essential hypertension. Clin Genet. 1997 Jan;51(1):31-4. doi: 10.1111/ j.1399-0004.1997.tb02410.x.

19. Fedorov AI, Klimova TM, Fedorova VI, Baltakhinova ME. [Food and lifestyle of the indigenous rural population of Yakutia]. Yakut Medical Journal. 2015;3:69-72. [Article in Russian].

20. Whelton PK, Carey RM, Aronow WS, Casey DE Jr, Collins KJ, Dennison Himmelfarb C, et al. 2017 ACC/AHA/ AAPA/ABC/ACPM/AGS/APhA/ASH/ASPC/NMA/PCNA Guideline for the Prevention, Detection, Evaluation, and Management of High Blood Pressure in Adults: A Report of the American College of Cardiology/American Heart Association Task Force on Clinical Practice Guidelines. J Am Coll Cardiol. 2018 May 15;71(19):e127-e248. doi: 10.1016/j. jacc.2017.11.006.

21. dbSNP Short Genetic Variations [Electronic resource]. 2021. URL: Avaiavle from: https://www.ncbi.nlm.nih.gov/ snp/rs5186?vertical_tab=true\#frequency_tab.

22. Liu Y, Zhuoma C, Shan G, Cui C, Hou S, Qin W, Cai D, Gesang L, Xiao Z, Pingcuo Z, Zheng H, Wu Z, Zhou W, Qiu C. A1166C polymorphism of the angiotensin II type 1 receptor gene and essential hypertension in Han, Tibetan and Yi populations. Hypertens Res. 2002 Jul;25(4):515-21. doi: 10.1291/hypres.25.515.

23. Chandra S, Narang R, Sreenivas V, Bhatia J, Saluja D, Srivastava K. Association of angiotensin II type 1 receptor (A1166C) gene polymorphism and its increased expression in essential hypertension: a case-control study. PLoS One. 2014 Jul 3;9(7):e101502. doi: 10.1371/journal.pone.0101502.

24. Ono K, Mannami T, Baba S, Yasui N, Ogihara T, Iwai
N. Lack of association between angiotensin II type 1 receptor gene polymorphism and hypertension in Japanese. Hypertens Res. 2003 Feb;26(2):131-4. doi: 10.1291/hypres.26.131.

25. Dzida G, Sobstyl J, Puzniak A, Golon P, Mosiewicz J, Hanzlik J. Polymorphisms of angiotensin-converting enzyme and angiotensin II receptor type 1 genes in essential hypertension in a Polish population. Med Sci Monit. 2001 Nov-Dec;7(6):1236-41.

26. Ayadi Kabadou I, Soualmiaa H, Jemaa R, Feki M, Kallel A, Souheil O, Haj Taieb S, Sanhaji H, Kaabachi N. Lack of association between C3123A polymorphism of the angiotensin II type 2 receptor gene and hypertension in Tunisian population. Tunis Med. 2012 Aug-Sep;90(8-9):619-24.

27. Musso G, Saba F, Cassader M, Paschetta E, De Michieli F, Pinach S, et al. Angiotensin II Type 1 Receptor rs5186 Gene Variant Predicts Incident NAFLD and Associated Hypertension: Role of Dietary Fat-Induced Pro-Inflammatory Cell Activation. Am J Gastroenterol. 2019 Apr;114(4):607619. doi: 10.14309/ajg.0000000000000154.

28. Yap RWK, Shidoji Y, Yap WS, Masaki M. Association and Interaction Effect of AGTR1 and AGTR2 Gene Polymorphisms with Dietary Pattern on Metabolic Risk Factors of Cardiovascular Disease in Malaysian Adults. Nutrients. 2017 Aug 9;9(8):853. doi: 10.3390/nu9080853.

29. Eshraghian A, Iravani S, Azimzadeh P. The Association between Angiotensin II Type 1 Receptor Gene A1166C Polymorphism and Non-alcoholic Fatty Liver Disease and Its Severity. Middle East J Dig Dis. 2018 Apr;10(2):96-104. doi: 10.15171/mejdd.2018.97.

30. Palatini P, Ceolotto G, Dorigatti F, Mos L, Santonastaso M, Bratti P, Papparella I, Pessina AC, Semplicini A. Angiotensin II type 1 receptor gene polymorphism predicts development of hypertension and metabolic syndrome. Am J Hypertens. 2009 Feb;22(2):208-14. doi: 10.1038/ajh.2008.319. 